\title{
Reproductive characteristics of the polymorphic Caribbean reef building coral Montastrea annularis. II. Fecundity and colony structure
}

\author{
Manfred L. J. Van Veghel ${ }^{1,2}$, Marli E. H. Kahmann ${ }^{1}$ \\ ${ }^{1}$ CARMABI Foundation - Ecological Institute, PO Box 2090, Curaçao, Netherlands Antilles \\ ${ }^{2}$ University of Amsterdam, Institute of Taxonomic Zoology, PO Box 4766, 1009 AT Amsterdam, The Netherlands
}

\begin{abstract}
We studied reproductive characteristics of 3 Montastrea annularis (Ellis \& Solander) morphotypes (viz. 'Bumpy', 'Massive' and 'Columnar'; Van Veghel \& Bak 1993, Mar. Ecol. Prog. Ser. 92: 255-265) by dissecting about 2450 polyps in the reproductive seasons of 1991 and 1992 . Fecundity, number of gonads per polyp, and fertility were found to be significantly different between the studied morphotypes (ANOVA, $p<0.001$ ), ranking from high to low in Bumpy. Massive, and Columnar morphotypes. Gonads as percent of total biomass also varied, but were not significantly different for Bumpy (29.7\%) versus Massive $(22.0 \%$ ) and Columnar $(20.9 \%)$ morphotypes. Columnar colonies with interconnected living tissue larger than $50 \mathrm{~cm}^{2}$ were already fully reproductive whereas in other morphotypes fecundity was significantly (ANOVA, $p<0.001$ ) reduced in colonies smaller than $300 \mathrm{~cm}^{2}$. Significant differences (ANOVA, $p<0.05$ ) in fecundity occurred between 2 consecutive years for the Massive morph. On a geographic scale, fecundity of $M$. annularis populations on Curaçao was 5 to 14 times lower than in Puerto Rico. Coral species with comparable reproductive strategy all had higher fecundities than $M$. annularis in this study. Fecundity and reproductive traits in $M$. annularis appear to correlate with colony morphology.
\end{abstract}

KEY WORDS: Reproduction · Fecundity · Corals · Caribbean · Montastrea annularis $\cdot$ Polymorphism

\section{INTRODUCTION}

Although data on coral sexual reproduction has increased enormously in the last decade (Harrison \& Wallace 1990), reproductive data are available only for about $30 \%$ of known scleractinian reef corals (Richmond \& Hunter 1990) and few generalizations concerning ecological consequences of sexual reproduction can be made (Shlesinger \& Loya 1985). Studies so far have revealed that coral reproductive strategies are very complex, e.g. there are different reproductive modes for the same species in different geographical areas (Rinkevich \& Loya 1979) and for assumed growth forms (Van Moorsel 1983). Such complexity and lack of data on reproductive energy demand in relation to life history aspects, environmental variability or colony structure are reasons for our inability to make generalizations.
Data available on energetic relationships between reproduction and life history aspects include: growth rate (Chornesky \& Peters 1987, Richmond 1987), regeneration and survival (Babcock 1988, Rinkevich \& Loya 1989, Van Veghel \& Bak 1994), and recruitment success (Richmond 1981, Sammarco \& Andrews 1989). Studies on environmental conditions and coral reproduction have reported a negative relationship between fecundity and external stress factors (Kojis \& Quinn 1984, Jokiel 1985 , Rinckevich \& Loya 1987, Tomascik \& Sander 1987, Szmant \& Gassman 1990, Glynn et al. 1991).

The present paper examines reproductive characteristics of 3 morphotypes of the reef building coral Montastrea annularis (Ellis \& Solander): viz. 'Bumpy', 'Massive' and 'Columnar' (Van Veghel \& Bak 1993, Weil \& Knowlton 1994). M. annularis is a hermaphroditic broadcast spawner and premating characteristics, i.e. reproductive mode, development and maturation 
of the gametes and spawning behavior were not different for these morphotypes (Van Veghel 1994). Here we report on the differences in reproductive effort and fecundity of the $M$. annularis morphotypes.

We used dissection techniques to study fecundity (number of eggs per polyp per year) and other reproductive characteristics for each morphotype. Fecundity was studied in relation to polyp diameter, polyp biomass, colony size and distance to living colony edge during the reproductive seasons of 1991 and 1992 on Curaçao, Netherlands Antilles. The results are compared with Montastrea annularis data from other localities and with other coral species.

\section{MATERIALS AND METHODS}

Montastrea annularis morphotypes on Curaçao spawn eggs and sperm in the week after full moon in September and October (Van Veghel 1993, 1994). A week before the first and major spawning in September 1991 and 1992 samples of the $3 \mathrm{M}$. annularis morphotypes were collected at depths between 6 and $25 \mathrm{~m}$. During the 1991 reproductive season we studied fecundity (number of eggs per polyp per year), fertility (\% polyps with eggs), and \% gonads of the total biomass. Study sites were Awa Blancu (AB), CARMABI Buoy 1 (B1) and Slangenbaai (SB) (Bak 1975, Van Duyl 1985, Van Veghel \& Bak 1993). In 1992, we studied fecundity in different size classes and the effect on reproduction of distance of polyps to the living colony edge. All 1992 samples were collected at location B1.

Material. Samples (approximately $20 \mathrm{~cm}^{2}$ ) were collected using a hammer and chisel, stored in numbered mosquito-gauze bags in seawater and put in Bouin's fixative. After fixation ( 24 to $48 \mathrm{~h}$ ), samples were rinsed with running tap-water for 12 to $24 \mathrm{~h}$ before they were decalcified using a formic acid and sodium citrate treatment (Rinkevich \& Loya 1979). Polyps were dissected with forceps and scalpel and examined with a dissecting microscope.

Gonad biomass. To obtain gonad:polyp biomass ratios, up to 10 polyps carrying gonads per colony were dissected until about 100 fertile polyps per morphotype were obtained. The number of eggs per gonad and gonads per polyp were examined and gonad material and polyp tissue were separately dried in small porcelain cups at $55^{\circ} \mathrm{C}$ to constant weight.

Fertility and polyp diameter. Twenty-five interconnected polyps of 9 colonies per morphotype were dissected to study fertility and fertility in relation to polyp diameter (measured at the polyp base). All polyps were included in this part of the study, whereas in the other parts polyps smaller than $2 \mathrm{~mm}$ in diameter were not examined.
Fecundity versus colony size. To study the influence of colony size, we collected 5 samples per morph of the 4 smaller size classes, viz. 1-49, 50-99, 100-199, 200-300 $\mathrm{cm}^{2}$, and 10 for the largest size class, viz. $>300 \mathrm{~cm}^{2}$. Ten polyps per sample were dissected. To study the differences between the 2 years, fecundity data of samples from colonies larger than $300 \mathrm{~cm}^{2}$ collected in 1991 and 1992 were compared. The effect of the distance to the colony edge on reproduction was studied by dissecting the first 5 peripheral rows of polyps. About 20 polyps from 6 different colonies were examined per morphotype.

Statistics. Frequency differences between size classes and the experimental sample sets and their controls were tested using a 1-way ANOVA. Data was checked with Barlett's test for homogeneity of variance, and the Kolmogorov-Smimov test for normality (Sokal \& Rohlf 1981).

\section{RESULTS}

\section{Fecundity}

The average fecundity, number of gonads per polyp and eggs per gonad (combined data from 1991 and 1992; Table 1) were significantly different for the 3 morphotypes (ANOVA, p $<0.001$ ). Mean fecundity (SD) was estimated at 71 (59), 30 (39) and 19 (31) eggs per polyp, for the Bumpy, Massive and Columnar morphotypes, respectively.

\section{Gonad biomass}

The biomass of reproductive products as percentage of total polyp biomass for Bumpy, Massive and Columnar, was $28.7 \%, 22.0 \%$ and $20.9 \%$ respectively (Table 1), values which were not significantly different. The annual production of reproductive biomass $\mathrm{cm}^{-2}$ was calculated by multiplying the average of eggs per polyp, the number of polyps $\mathrm{cm}^{-2}$ (Van Veghel \& Bak 1993) and the percentage fertile polyps (Table 1). Estimated values were 3.49, 1.74 and $1.92 \mathrm{mg}$ $\mathrm{cm}^{-2}$, for the Bumpy, Massive and Columnar morphs respectively. The volume production was calculated using $0.023425 \mathrm{~mm}^{3}\left(\mathrm{SD}=1.01 \times 10^{-5}\right)$ as a standard for egg volume (Van Veghel unpubl.; Table 1).

\section{Fertility and polyp diameter}

The Bumpy morphotype showed a significantly higher fertility (ANOVA, $\mathrm{p}<0.001$ ), with an average of $89 \%$ of all polyps carrying gonads. Differences 
Table 1. Montastrea annularis. Fecundity (eggs per polyp per year) and other reproductive characteristics of the morphotype complex on Curaçao. (Weights are dry weight)

\begin{tabular}{|c|c|c|c|}
\hline \multirow[t]{2}{*}{ Reproductive character } & \multicolumn{3}{|c|}{ Morphotype } \\
\hline & Bumpy & Massive & Columnar \\
\hline \multicolumn{4}{|l|}{ Years: $1991+1992$} \\
\hline $\mathrm{N}$ & 239 & 302 & 315 \\
\hline Fecundity (SD) & 71 (59) & $30(39)$ & $19(31)$ \\
\hline Gonads per polyp (SD) & $9.2(6.9)$ & $4.6(5.5)$ & $3.2(4.7)$ \\
\hline Eggs per gonad (max.) & $7.7(4.0)$ & $6.5(2.5)$ & $5.9(2.3)$ \\
\hline \multicolumn{4}{|l|}{ Year: 1991} \\
\hline$N$ & 65 & 58 & 61 \\
\hline Gonad weight $(\mu \mathrm{g})$ & 85 & 68 & 73 \\
\hline $\begin{array}{l}\text { Gonad per } \\
\text { total weight }(\%)\end{array}$ & 28.7 & 22.0 & 20.9 \\
\hline $\begin{array}{l}\text { Range gonad per } \\
\text { total weight }(\%)\end{array}$ & $9.0-50.9$ & $7.1-35.1$ & $7.5-31.6$ \\
\hline $\begin{array}{l}\text { Gonad per } \\
\text { total weight (mg) }\end{array}$ & 1.04 & 0.56 & 0.61 \\
\hline $\begin{array}{l}\text { Gonad production } \\
\left(\mathrm{mg} \mathrm{cm}^{-2} \mathrm{yr}^{-1}\right)\end{array}$ & 3.49 & 1.74 & 1.92 \\
\hline $\begin{array}{l}\text { Gonad volume production } \\
\left(\mathrm{mm}^{3} \mathrm{~cm}^{-2} \mathrm{yr}^{-1}\right)\end{array}$ & 6.02 & 3.14 & 2.39 \\
\hline \multicolumn{4}{|l|}{ Year: 1991} \\
\hline $\mathrm{N}$ & 225 & 225 & 225 \\
\hline Average fertility $(\%)$ & 89 & 61 & 58 \\
\hline Maximum fertility (\%) & 100 & 93 & 80 \\
\hline Smallest fertile polyp (mm) & 1.43 & 1.89 & 1.69 \\
\hline Fertility polyps (>2 mm) (\%) & 91 & 69 & 64 \\
\hline Annual fecundity $\left(\mathrm{cm}^{-2}\right)$ & 257 & 134 & 102 \\
\hline
\end{tabular}

between the Massive and Columnar morphotypes, with averages of $61 \%$ and $58 \%$ respectively, were not significant (Table 1). Fertility was positively correlated with polyp diameter (Fig. 1). A $100 \%$ fertility was only reached by the Bumpy morphotype for polyps over $3 \mathrm{~mm}$ in diameter. Maximum fertility of the Massive $(93 \%)$ and Columnar $(80 \%)$ morphotypes was reached in the 3 to $3.5 \mathrm{~mm}$ class.

\section{Fecundity at different localities}

At location AB fecundity was significantly higher for the Bumpy morphotype (Table 2; ANOVA, $p<0.01$ ) compared to B1 and SB. Massive and Columnar morphotypes did not differ significantly between $\mathrm{AB}$ and $\mathrm{SB}$, but at these localities fecundity was significantly higher (Table 2; ANOVA, $p<0.05$ ) than at B1.

\section{Fecundity during 1991 vs 1992}

Overall fecundity was lower in 1991 at location $B 1$, but differences were not significant for the
Bumpy and Columnar morphs (Table 2). The Massive morph showed a significantly higher fecundity and number of gonads/polyp in 1992 (ANOVA, $\mathrm{p}<0.05)$.

\section{Fecundity versus colony size}

All colony size classes of the Bumpy morphotype had reproductive polyps (Table 3). Fecundity was, however, significantly lower (Table 3; ANOVA, p < $0.001)$ in smaller colonies $\left(<300 \mathrm{~cm}^{2}\right)$. In the Columnar morphotype, reproduction was delayed until colonies were larger than $50 \mathrm{~cm}^{2}$ (Table 3). At this size, at the onset of reproduction, colonies were at maximum reproduction, with reproductive output sometimes even significantly higher (Table 3; ANOVA, p < 0.05) than for the largest size class. In comparison, colonies of the Massive morph were infertile until larger than $100 \mathrm{~cm}^{2}$.

In general, fecundity and the number of gonads per polyp as well as the number of eggs per gonad increased with colony size in Bumpy and Massive morphotypes (Table 3). In colonies of an immature size, 2 different egg size classes were observed, i.e. mature and immature eggs.

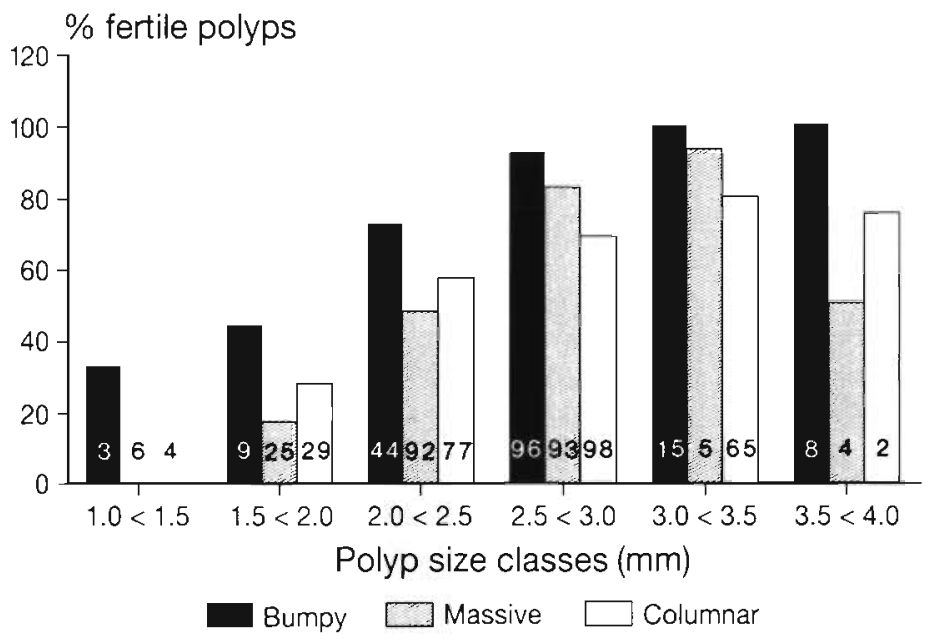

Fig. 1. Montastrea annularis. Percentage of fertile polyps versus polyp size for 3 morphotypes at Curaçao. Numbers in columns are sample sizes. $\mathrm{n}=225$ polyps per morph 
Table 2. Montastrea annularis. Temporal and spatial variation in fecundity and number of gonads per polyp of the morphotype complex at Curaçao. One-way ANOVA tests for differences between localities and reproductive seasons. $\cdots p<0.001 ; \cdots 0.001<p<0.01 ; \cdot p<0.05 ;$ ns = not significant. Localities: $\mathrm{AB}=\mathrm{Awa}$ Blancu, $\mathrm{B} 1=\mathrm{CARMABI}$ Buoy $1, \mathrm{SB}=$ Slangenbaal

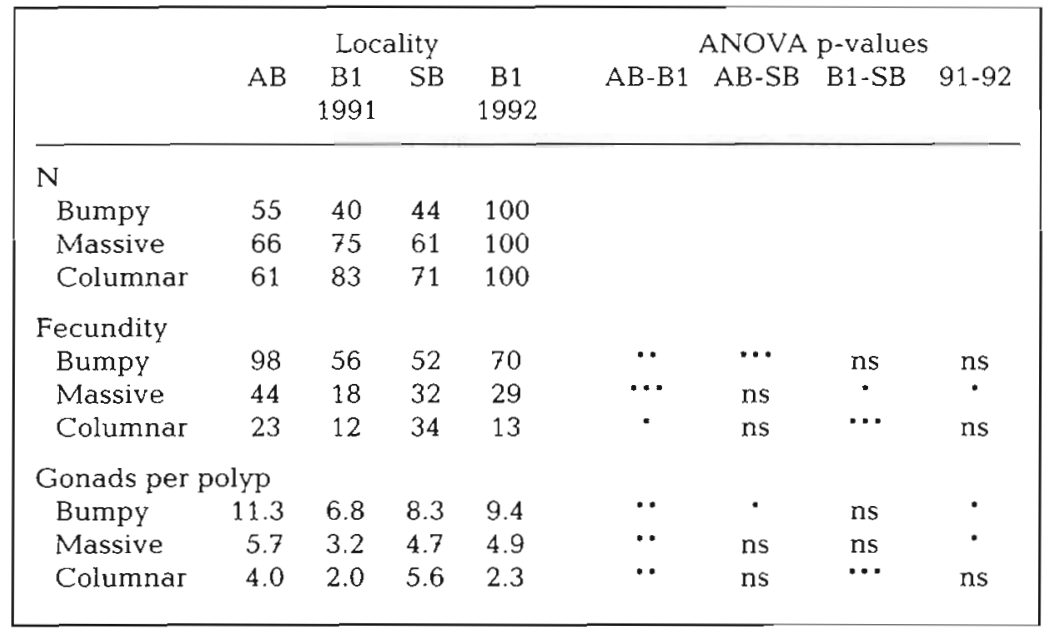

colonies, respectively. In the Massive morph, no eggs were found in marginal polyps.

\section{DISCUSSION}

There appear to be significant differences in fecundity and other reproductive characteristics between Montastrea annularis morphotypes. Overali, reproductive ability was highest for the Bumpy morphotype, and significantly lower for the Columnar morphotype, which is however mature at smaller size.

Annually Montastrea annularis morphs invest between $20.9 \%$ (Columnar) and $28.7 \%$ (Bumpy) of biomass into reproductive tissue. Szmant (1991) calculated the annual release of reproductive biomass at 30 to $40 \%$ for $M$. annularis (Massive morphotype) collected in

\section{Fecundity versus distance to colony edge}

In all morphotypes, fecundity of the first 5 rows of polyps (ca $20 \mathrm{~mm}$ ) was significantly lower (ANOVA, $\mathrm{p}<0.001$ ) compared to polyps sampled from the middle of the colony. The average number of eggs per gonad was 4.3 and 3.4 for Bumpy and Columnar

Table 3. Montastrea annularis. Intraspecific variation in reproductive characteristics in relation to colony sizes $\left(\mathrm{cm}^{2}\right)$ of the morphotype complex on Curaçao. One-way ANOVA tests for differences between the smaller sized colonies and colonies larger than $300 \mathrm{~cm}^{2} ; \cdots p<0.001 ; \cdots 0.001<p<0.01$; $\cdot p<0.05 ;$ ns $=$ not significant

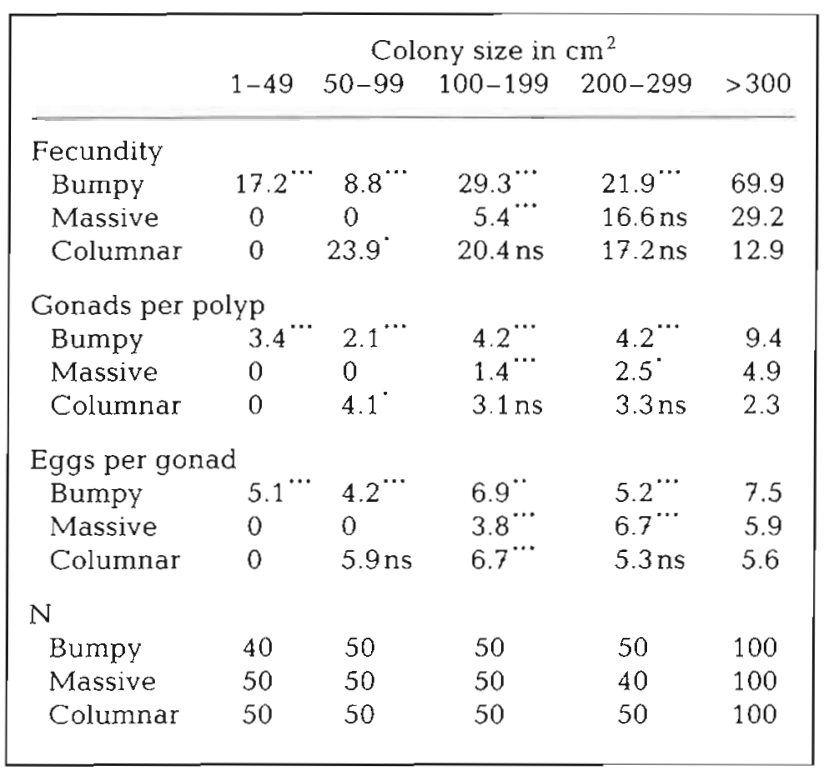

Puerto Rico. The Pacific coral Pocillopora damicornis (Linneaus) in Hawaii released a minimum of 25 to $50 \%$ of its total colony biomass as planulae annually (Jokiel 1985). Richmond (1987) observed that the same species released 20 to $167 \%$ (average $64 \%$ ) of the total calorific content of the parent colony in Enewetak. In view of these data, $M$. annularis reproductive ability at Curaçao appears low. This is also true when fecundity is compared on an area basis. Fecundity per surface area (eggs $\mathrm{cm}^{-2} \mathrm{yr}^{-1}$ ) was significantly higher for the Bumpy (257) in comparisons with the Massive (134) and Columnar (102) morphotypes. Caribbean coral species with comparable growth forms and reproductive strategies have considerably higher values than the $M$. annularis morphotypes: Diploria strigosa (Dana) (350), Dendrogyra cylindricus (Ehrenberg) (480), Montastrea cavernosa (Linneaus) (576), M. annularis from Puerto Rico (1440) and Siderastrea siderea (Ellis \& Solander) (2187) (all eggs $\mathrm{cm}^{-2} \mathrm{yr}^{-1}$; calculations by Harrison \& Wallace 1990). Because of differences in methodology and unknown variability in fecundity with regard to geographic and temporal variation, we tentatively conclude that the reproductive output of $M$. annularis on Curaçao is lower than that calculated for $M$. annularis in Puerto Rico and for other coral species. Large differences in fecundity at geographic distant localities were also found by Glynn et al. (1994).

A relatively low reproductive effort is consistent with demographic and life history aspects for $K$-selected species (MacArthur \& Wilson 1967, Krebs 1978). Other characteristics of Montastrea annularis in favour of $K$-selection are low larval recruitment rate (Bak \& Engel 1979), relatively low growth rate, proportionate 
large colonies, low whole colony and partial mortality (Bak \& Luckhurst 1980, Hughes \& Jackson 1985) as well as moderate regeneration capacity (Bak 1983, Meesters et al. 1992, Meesters \& Bak 1993) and moderate interspecific competitive abilities (Lang 1973, Bak et al. 1982).

That fertility and fecundity vary spatially over the colony surface within reproductively mature colonies has been shown for many coral species (Rinkevich \& Loya 1979, Wallace 1985, Szmant 1991, Soong \& Lang 1992). This is confirmed for the Montastrea annularis morphotypes. Polyps of the Massive morph were found to be infertile at the colony's periphery, and in the other 2 morphotypes, fecundity was reduced. We did not measure the colony circumference and cannot estimate the total area where fecundity was reduced. Our data are consistent with those of Soong \& Lang (1992) who found that 4 other massive Caribbean colonies with distinct polyps were infertile, varying from 1 to 10 rows of polyps ( 0 to $2 \mathrm{~cm}$ ) adjacent to natural colony margins.

Harriot (1983) found a positive correlation between fertility and polyp size in the coral Lobophyllia corymbosa (Forskal) and suggested that polyp size rather than colony size limits gonad production. Although fertility and polyp size were positively correlated for all 3 Montastrea annularis morphotypes, polyps of mature size $(>2 \mathrm{~mm})$ in small colonies were not all reproductive. A higher budding rate in the Massive and Columnar morphotypes (the number of small polyps $(<2 \mathrm{~mm}$ ) is about 3 times higher than in the Bumpy morphotype) may explain why less mature sized polyps were reproductive. More space becomes available as a consequence of the colony shape and a higher growth rate for the Massive and Columnar morphotypes (Tomascik 1990, Knowlton et al. 1992, Van Veghel \& Bosscher unpubl.). A potentially important role of the curvature of the skeletal surface on intracolony reproductive aspects was also hypothesized by Soong \& Lang (1992).

A positive correlation between sexual reproductive potential and colony size, an essential feature of clonal strategies (Jackson \& Coates 1986), was observed in other scleractinian species (Jackson 1985, SzmantFroelich 1985, Babcock 1988), and can be confirmed for the studied morphotypes. However, differences were observed in size at full reproduction. The smallest Massive and Columnar morphotypes are infertile, and while the polyps of small Bumpy colonies carry gonads, their fecundity is significantly lower compared to large colonies $\left(>300 \mathrm{~cm}^{2}\right.$ ). Full reproductive potential is reached for the Columnar morph with living tissue in the size range 50 to $99 \mathrm{~cm}^{2}$. The other 2 morphotypes have a lower fecundity for all size classes smaller than $300 \mathrm{~cm}^{2}$. Although the Columnar morph can form huge colonies, the area of interconnected tissue is much lower than in the 2 other morphotypes. Living tissue can only be found at the top of the colony columns, and different columns usually do not share connecting tissue. Reaching full reproductive potential at a relatively small size may be considered an adaptation to colony morphology for Columnar colonies. Data collected for the Bumpy and Massive morphotypes are comparable with those of Szmant-Froelich (1985). She suggests that Montastrea annularis colonies are fully reproductive at a size larger than $200 \mathrm{~cm}^{2}$. Data from Curaçao show a full reproductive size for Bumpy and Massive morphs larger than $300 \mathrm{~cm}^{2}$ and for the Columnar morph larger than $50 \mathrm{~cm}^{2}$. Most massive Caribbean corals studied by Soong \& Lang (1992) are fully reproductive when they reach a size of 250 to $1000 \mathrm{~cm}^{2}$. The 2 different egg sizes observed in our study in small, not fully reproductive, colonies may be an indication that energy allocation to reproductive tissue is limited by colony size.

Possible relations between environmental factors and coral fecundity were studied by Kojis \& Quinn (1984). They found a negative correlation between fecundity and depth, turbidity and sedimentation. In our study, location B1 was found to have a significant lower fecundity for all 3 morphs. This location is overall more disturbed than the other 2 study areas because of its position close to the Piscadera Baai inlet and densely populated and industrial areas. When more data become available on the relationships between environmental stress and fecundity, fecundity may be used as a good and simple indicator of coral 'health'.

Rinkevich \& Loya (1987) found fecundity to show considerable variation between consecutive reproductive seasons, i.e. high fecundity in one season and sterility in the next or vice versa. They also observed that population fecundity was highly variable between successive years, influenced by such factors as storms. At our study sites, except for the construction of an artificial beach $1.5 \mathrm{~km}$ upstream of location B1, no important changes occurred. The observed annual differences in fecundity, ranging from 8 to $61 \%$ (calculated from Table 3), and only significant for the Massive morphotype, most probably indicate a natural range of annual variation.

In conclusion, there are significant differences in fecundity and other reproductive characteristics between the 3 morphotypes of Montastrea annularis. The Bumpy morphotype exhibits a higher reproductive effort than the 2 other morphotypes. Reproduction in this morph starts when colonies are small, and is significantly higher than the 2 other morphotypes in large colonies. Large $\left(>300 \mathrm{~cm}^{2}\right)$ Columnar and Massive colonies are not very different in reproductive charac- 
teristics. However, the reproductive output of the population of columnar morphs could be considerably higher because Columnar colonies reach full reproduction at a much smaller size.

Acknowledgements. We are grateful to the CARMABI Foundation for providing research facilities, and to diving buddies Aubrey Tiel, Frank Isabella and Oscar Frans for their help during collections. Prof. Rolf P. M. Bak and 2 anonymous reviewers provided valuable comments on the manuscript. This research was supported financially by the Department of Biology of the University of Amsterdam.

\section{LITERATURE CITED}

Babcock, R. C. (1988). Age-structure, survivorship and fecundity in populations of massive corals. Proc. 6th int. coral Reef Symp. 2: 625-633

Bak, R. P. M. (1975). Ecological aspects of the distribution of reef corals in the Netherlands Antilles. Bijdr. Dierk. 45: $181-190$

Bak, R. P. M., Engel, M. S. (1979). Distribution, abundance and survival of juvenile hermatypic corals (Scleractinia) and the importance of life history strategies in the parent coral community. Mar. Biol. 54: 341-352

Bak, R. P. M., Luckhurst, B. E. (1980). Constancy and change in coral reef habitats along depth gradients at Curaçao. Oecologia 47: 145-155

Bak, R. P. M., Termaat, R. M., Dekker, R. (1982). The complexity of coral interactions: influence of time, location of interaction and epifauna. Mar. Biol. 69: 215-222

Bak, R. P. M. (1983). Neoplasia, regeneration and growth in the reef building coral Acropora palmata. Mar. Biol. 77 : 221-227

Chornesky, E. A., Peters, E. C. (1987). Sexual reproduction and colony growth in the scleractinian coral Porites astreoides. Biol. Bull. 172(2): 161-177

Glynn, P. W., Gassman, N. J., Eakin, C. M., Cortes, J., Smith, D. B., Guzman, H. M. (1991). Reef coral reproduction in the eastern Pacific: Costa Rica, Panama, and Galapagos Islands (Ecuador). I. Pocilloporidae. Mar. Biol. 109: $355-368$

Glynn, P. W., Colley, S. B., Eakin, C. M., Smith, D. B., Cortés, J., Gassman, N. J., Guzmán, H. M., Del Rosario, J. B., Feingold, J. S. (1994). Reef coral reproduction in the eastern Pacific: Costa Rica, Panamá, and Galápagos Islands (Ecuador). II. Poritidae. Mar. Biol. 118: 191-208

Harriot, V J. (1983). Reproductive ecology of four scleractinian species at Lizard Island, Great Barrier Reef. Coral Reefs 2: $9-18$

Harrison, P. L., Wallace, C. C. (1990). Reproduction, dispersal and recruitment of scleractinian corals, In: Dubinsky, $Z$. (ed.) Ecosystems of the world 25. Coral reefs. Elsevier, Amsterdam, p. 133-207

Hughes, T P., Jackson, J. B. C. (1985). Population dynamics and life histories of foliaceous corals. Ecol. Monogr. 55: $141-166$

Jackson, J. B. C. (1985). Distribution and ecology of clonal and aclonal benthic invertebrates. In: Jackson, J. B. C., Buss, L. W., Cook, R. E. (eds.) Population biology and evolution of clonal organisms. Yale University Press, New Haven, p. $297-356$

Jackson, J. B. C, Coates, A. G. (1986). Life cycles and evolution of clonal (modular) animals. Proc. Trans. R. Soc. Lond. B 313: 7-22
Jokiel, P. L. (1985). Lunar periodicity of planula release in the reef coral Pocillopora damicornis in relation to various environmental factors. Proc. 5th int. coral Reef Congress 4 : 307-312

Knowlton, N., Weil, E., Weigt, L. A., Guzmán, H. (1992). Sibling species in Montastrea annularis, coral bleaching, and the coral climate record. Science 255: 330-332

Kojis, B. L., Quinn, N. J. (1984). Seasonal and depth variation in fecundity of Acropora palifera at two reefs in Papua New Guinea. Coral Reefs 3: 165-172

Krebs, C. J. (1978). Ecology: the experimental analysis of distribution and abundance. Harper \& Row, New York, p. 678

Lang. J. (1973). Interspecific aggression by scleractinian corals. 2. Why the race is not only to the swift. Bull. mar. Sci. 23(2): 260-279

MacArthur, R. H., Wilson, E. O. (1967). The theory of island biogeography. Princeton University Press, Princeton, New York

Meesters, E. H., Bos, A., Gast G. J. (1992). Effects of sedimentation and lesion position on coral tissue regeneration. Proc. 7th int. coral Reef Symp., Guam (in press)

Meesters, E. H., Bak, R. P. M. (1993). Effects of coral bleaching on tissue regeneration potential and colony survival. Mar. Ecol. Prog. Ser. 96: 189-198

Richmond, R. H. (1981). Energetic considerations in the dispersal of Pocillopora damicornis (Linnaeus) planulae. Proc. 4th int coral Reef Symp. 2: 153-156

Richmond, R. H. (1987). Energetic relationships and biogeographical differences among fecundity, growth and reproduction in the coral Pocillopora damicornis. Bull. mar. Sci. 41(2): 595-604

Richmond, R. H., Hunter, C. L. (1990). Reproduction and recruitment of corals: comparison among the Caribbean, the Tropical Pacific, and the Red Sea. Mar. Ecol. Prog. Ser. 60: $185-203$

Rinkevich, B., Loya, Y. (1979). The reproduction of the Red Sea coral Stylophora pistillata. II. Synchronization in breeding and seasonality of planulae shedding. Mar. Ecol. Prog. Ser. 1: 145-152

Rinkevich, B., Loya, Y (1987). Variability in the pattern of sexual reproduction of the coral Stylophora pistillata at Eilat, Red Sea: a long term study. Biol. Bull. 173: $335-344$

Rinkevich, B., Loya, Y (1989). Reproduction in regenerating colonies of the coral Stylophora pistillata. In: Spanier, E., Steinberger, Y., Luria, M. (eds.) Environmental quality and ecosystems stability: Vol. IV, Environmental quality. ISEEQS Publ., Jerusalem, p. 257-265

Sammarco, P. W., Andrews, J. C. (1989). The Helix experiment: differential localized dispersal and recruitment patterns in Great Barrier Reef corals. Limnol. Oceanogr 34(5): 896-912

Shlesinger, Y., Loya, Y (1985). Coral community reproductive patterns: Red Sea versus the Great Barrier Reef. Science 228: $1333-1335$

Sokal, R. R., Rohlf, F. J. (1981). Biometry. W. H. Freeman and Co., New York, p. 859

Soong, K., Lang, J. C. (1992). Reproductive integration in reef corals. Biol. Bull. 183: 418-431

Szmant, A. M. (1991). Sexual reproduction by the Caribbean reef corals Montastrea annularis and Montastrea cavernosa. Mar. Ecol. Prog. Ser. 74: 13-25

Szmant, A. M. Gassmann, N. J. (1990). The effects of prolonged 'bleaching' on the tissue biomass and reproduction of the reef coral Montastrea annularis. Coral Reefs 8: $217-224$ 
Szmant-Froelich, A. (1985). The effect of colony size on the reproduction ability of the Caribbean coral Montastrea annularis. Proc. 5th int. coral Reef Symp. 4: 295-300

Tomascik, T (1990). Growth rates of two morphotypes of Montastrea annularis along a eutrophication gradient, Barbados, W. I. Mar. Pollut. Bull. 21(8): 376-381

Tomascik, T., Sander, F. (1987). Effects of eutrophication on reef-building corals. II. Structure of scleractinian coral communities on fringing reefs, Barbados, West-Indies. Mar. Biol. 94: 53-75

Van Duyl, F. C. (1985). Atlas of the living reef of Curaçao and Bonaire (Netherlands Antilles). Foundation for Scientific Research in Surinam and the Netherlands Antilles, Vol. 117, Utrecht, p. 37

Van Moorsel, G. W. N. M. (1983). Reproductive strategies in two closely related stony corals (Agaricia, Scleractinia). Mar. Ecol. Prog. Ser. 13: 273-283

Van Veghel, M. L. J. (1993). Multiple species spawning on Curaçao reeis. Bull. mar. Sci. 52(3): 1017-1021

Van Veghel, M. L. J. (1994). Reproductive characteristics of

This article was submitted to the editor the polymorphic Caribbean reef building coral Montastrea annularis. I. Gametogenesis and spawning behavior. Mar. Ecol. Prog. Ser. 109: 209-219

Van Veghel, M. L. J., Bak, R. P. M. (1993). Intraspecific variation of a dominant Caribbean reef building coral, Montastrea annularis: genetic, behavioral and morphometric aspects. Mar. Ecol. Prog. Ser. 92: 255-265

Van Veghel, M. L. J., Bak, R. P. M. (1994). Reproductive characteristics of the polymorphic Caribbean reef building coral Montastrea annularis. III. Reproduction in damaged and regenerating colonies. Mar. Ecol. Prog. Ser. 109: $229-233$

Wallace, C. C. (1985). Seasonal peaks and annual fluctuations in recruitment of juvenile scleractinian corals. Mar. Ecol. Prog. Ser. 21: 289-298

Weil, E., Knowlton, N. (1994). A multi-character analysis of the Caribbean coral Montastrea annularis (Ellis \& Solander, 1786) and its two sibling species, $M$. faveolata (Ellis \& Solander, 1786) and M. franksi (Gregory, 1895). Bull. mar. Sci. (in press)

Manuscript first received: August 18, 1993

Revised version accepted: March 30, 1994 